\title{
REDOX BEHAVIOUR OF ANHYDROUS TRANSITION METAL PHOSPHATES
}

\author{
R. GLAUM, T. DROSS, M. BLUM, C. LITTERSCHEID, and H. THAUERN
}

Institut für Anorganische Chemie der Universität Bonn, Gerhard-Domagk Str. 1, D-53121 Bonn, Germany

e-mail: rglaum@uni-bonn.de

\begin{abstract}
Phase equilibria in ternary systems M / P / O, oxygen co-existence pressures in such systems, stabilisation of metals in rather low oxidation states and eventually electrical and optical charge transfer properties of phosphates are discussed for representative examples from our recent research. The observations are summarized with respect to the redox behaviour of anhydrous phosphates.
\end{abstract}

\section{INTRODUCTION}

The redox properties of anhydrous transition metal phosphates play a key role in many applications of such compounds. A particular redox potential is the prerequisite for heterogenous catalysts in oxidation and dehydrogenation reactions with alkanes. Redox equilibria between phosphate anti-corrosion coatings and metal substrates determine phase formation at the interface and hence the stability of the coating. Electrochemical applications of phosphates as solid electrolytes and/or electrode materials depend on their redox properties. Last but not least the mere existence of a particular phosphate depends on the mutual redox stability of cations and phosphate groups.

In this contribution we shall review some representative results from our recent research iluminating the redox behaviour of anhydrous phosphates.

\section{PHASE EQUILIBRIA IN SYSTEMS M / P / O}

In a systematic study we have determined phase equilibria present in systems $\mathrm{M} / \mathrm{P} / \mathrm{O}(\mathrm{M}=$ $\mathrm{Ti}, \mathrm{V}, \mathrm{Cr}, \mathrm{Mn}, \mathrm{Co}, \mathrm{Ni}, \mathrm{Cu}, \mathrm{Nb}, \mathrm{Mo}, \mathrm{W})[1]$. These investigations led also to the discovery and crystal structure determination of several new anhydrous phosphates (e. g.: $\mathrm{\square}_{2} \mathrm{Ti}_{4} \mathrm{O}_{3}\left(\mathrm{PO}_{4}\right)_{3}$ [2], $\mathrm{Cr}_{7}\left(\mathrm{PO}_{4}\right)_{6}[3], \mathrm{CuP}_{4} \mathrm{O}_{11}$ [4]). Equilibrium relations in the systems $\mathrm{Ti} / \mathrm{P} / \mathrm{O}$ and $\mathrm{Cu} / \mathrm{P} / \mathrm{O}$ differ dramatically and reflect the differences in the chemical properties of titanium and copper (FIGURE 1). $\mathrm{TiO}_{2}$ (at the lower phase boundary) and phosphorus (vapour) are coexisting, while phosphorus is reducing $\mathrm{CuO}$ to elemental copper, even when the oxide is already stabilised in a phosphate. Equilibrium relations for many other systems $\mathrm{M} / \mathrm{P} / \mathrm{O}$ are somewhere in between these two extremes (e. g. systems Co / P / O [5, 6] and Ni / P / O [6], FIGURE 2), showing a delicate balance between the reducing and oxidising properties of phosphorus vapour in contact with the equilibrium solids. This behaviour is illustrated by the redox behaviour of nickel phosphates and phosphides. $\mathrm{Ni}_{3}\left(\mathrm{PO}_{4}\right)_{2}$ reacts with phosphorus to $\mathrm{Ni}_{3} \mathrm{P}$ and $\mathrm{Ni}_{2} \mathrm{P}_{2} \mathrm{O}_{7}$ (1). The two-phase mixture reacts with additional phosphorus (2) to higher 
phosphides $\left(\mathrm{Ni}_{8} \mathrm{P}_{3}, \mathrm{Ni}_{12} \mathrm{P}_{5}\right)$ prior to further reduction of "NiO" in $\mathrm{Ni}_{2} \mathrm{P}_{2} \mathrm{O}_{7}$ followed by formation of $\mathrm{Ni}_{2} \mathrm{P}_{4} \mathrm{O}_{12}$ (3).

$$
\begin{aligned}
& 7 \mathrm{Ni}_{3}\left(\mathrm{PO}_{4}\right)_{2, \mathrm{~s}}+11 / 12 \mathrm{P}_{4, \mathrm{~g}}=8 \mathrm{Ni}_{2} \mathrm{P}_{2} \mathrm{O}_{7, \mathrm{~s}}+5 / 3 \mathrm{Ni}_{3} \mathrm{P}_{\mathrm{s}} \\
& 8 \mathrm{Ni}_{3} \mathrm{P}_{\mathrm{s}}+1 / 4 \mathrm{P}_{4, \mathrm{~g}}=3 \mathrm{Ni}_{8} \mathrm{P}_{3, \mathrm{~s}} \\
& 12 \mathrm{Ni}_{2} \mathrm{P}_{2} \mathrm{O}_{7, \mathrm{~s}}+49 / 24 \mathrm{P}_{4, \mathrm{~g}}=7 \mathrm{Ni}_{2} \mathrm{P}_{4} \mathrm{O}_{12, \mathrm{~s}}+25 / 6 \mathrm{Ni}_{12} \mathrm{P}_{5, \mathrm{~s}}
\end{aligned}
$$

$\mathrm{Ti}$

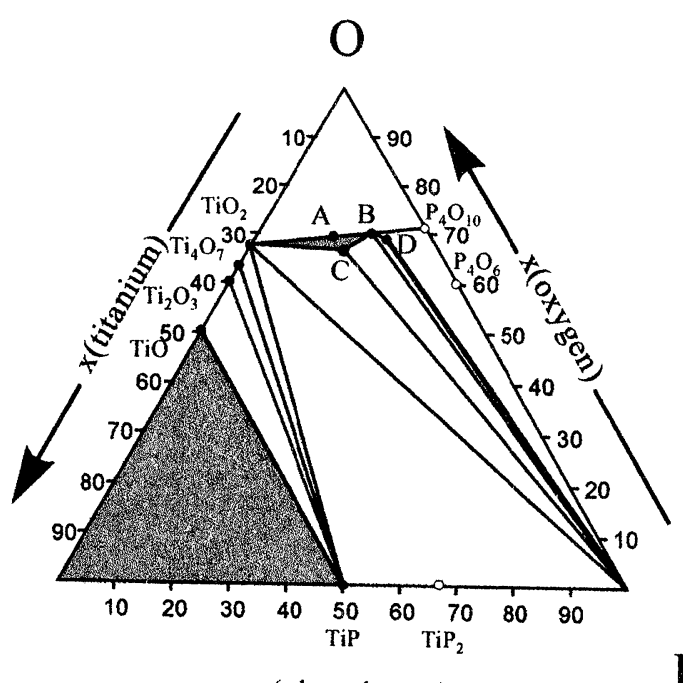

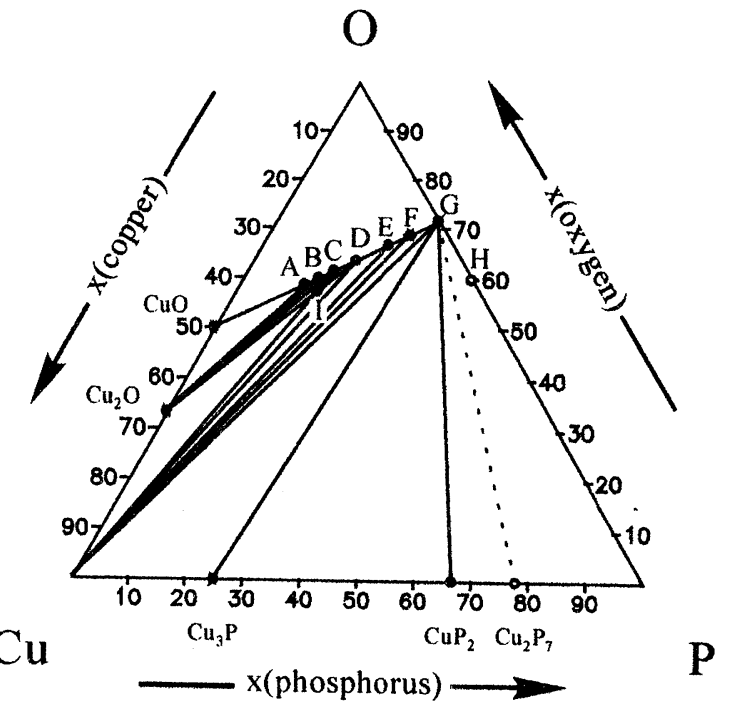

Figure 1 Gibbs phase triangles for the systems Ti / P / O $\left(900^{\circ} \mathrm{C}, \mathrm{A}: \mathrm{Ti}_{5} \mathrm{O}_{4}\left(\mathrm{PO}_{4}\right)_{4}, \mathrm{~B}: \mathrm{TiP}_{2} \mathrm{O}_{7}\right.$, $\mathrm{C}: \mathrm{TiPO}_{4}, \mathrm{D}: \mathrm{Ti}\left(\mathrm{PO}_{3}\right)_{3}$; additional phases $\square_{17} \mathrm{Ti}_{31} \mathrm{O}_{24}\left(\mathrm{PO}_{4}\right)_{24}, \square_{2} \mathrm{Ti}_{4} \mathrm{O}_{3}\left(\mathrm{PO}_{4}\right)_{3}$, and " $\mathrm{Ti}_{9} \mathrm{O}_{4}\left(\mathrm{PO}_{4}\right)_{8}$ " in the sub-triangle $\mathrm{TiO}_{2} / \mathrm{TiP}_{2} \mathrm{O}_{7} / \mathrm{TiPO}_{4}$ [2]; grey area: not investigated) and $\mathrm{Cu} / \mathrm{P} / \mathrm{O}\left(600^{\circ} \mathrm{C}, \mathrm{A}: \mathrm{Cu}_{5} \mathrm{O}_{2}\left(\mathrm{PO}_{4}\right)_{2}, \mathrm{~B}: \mathrm{Cu}_{4} \mathrm{O}\left(\mathrm{PO}_{4}\right)_{2}, \mathrm{C}: \mathrm{Cu}_{3}\left(\mathrm{PO}_{4}\right)_{2}, \mathrm{D}: \mathrm{Cu}_{2} \mathrm{P}_{2} \mathrm{O}_{7}, \mathrm{E}: \mathrm{Cu}_{2} \mathrm{P}_{4} \mathrm{O}_{12}\right.$, $\mathrm{F}: \mathrm{CuP}_{4} \mathrm{O}_{11}, \mathrm{G}: \mathrm{P}_{4} \mathrm{O}_{10}, \mathrm{H}: \mathrm{P}_{4} \mathrm{O}_{6}, \mathrm{I}: \mathrm{Cu}_{2} \mathrm{PO}_{4}$, references for the various phases are given in [1]).

O

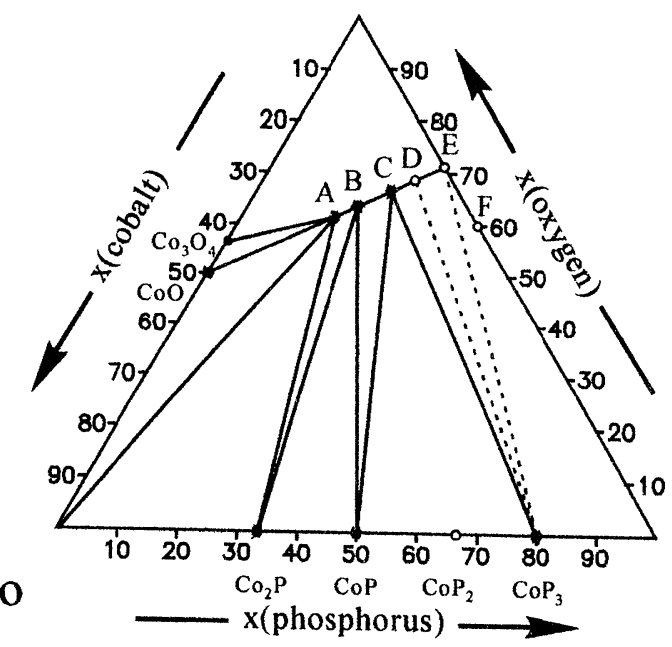

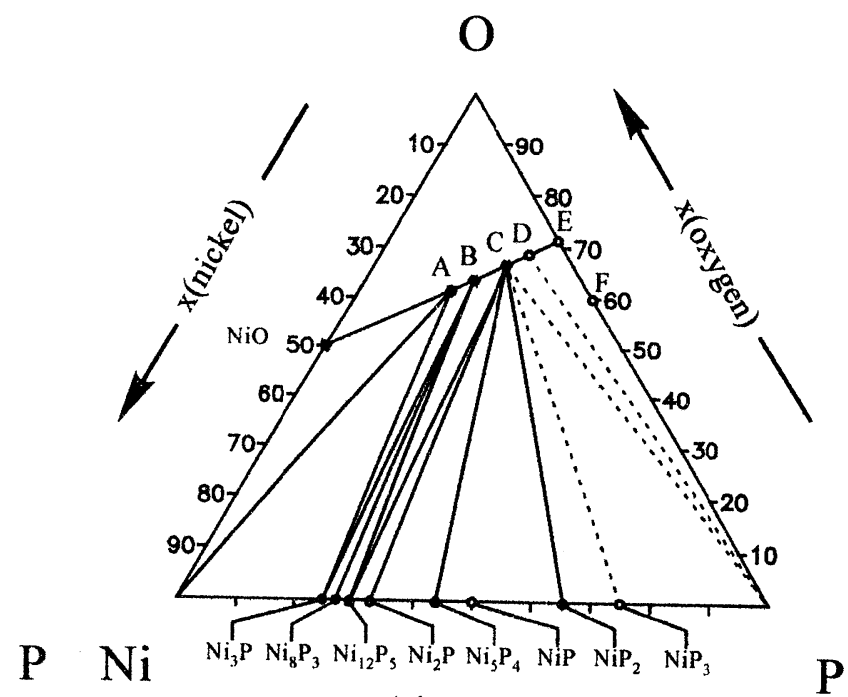

$\mathrm{x}$ (phosphorus)

Figure 2 Gibbs phase triangles for the systems Co / P / O $\left(900^{\circ} \mathrm{C}, \mathrm{A}: \mathrm{Co}_{3}\left(\mathrm{PO}_{4}\right)_{2}, \mathrm{~B}: \mathrm{Co}_{2} \mathrm{P}_{2} \mathrm{O}_{7}\right.$, C: $\left.\mathrm{Co}_{2} \mathrm{P}_{4} \mathrm{O}_{12}, \mathrm{D}: \mathrm{CoP}_{4} \mathrm{O}_{11}, \mathrm{E}: \mathrm{P}_{4} \mathrm{O}_{10}\right)$ and $\mathrm{Ni} / \mathrm{P} / \mathrm{O}\left(600^{\circ} \mathrm{C}, \mathrm{A}: \mathrm{Ni}_{3}\left(\mathrm{PO}_{4}\right)_{2}, \mathrm{~B}: \mathrm{Ni}_{2} \mathrm{P}_{2} \mathrm{O}_{7}, \mathrm{C}:\right.$ $\mathrm{Ni}_{2} \mathrm{P}_{4} \mathrm{O}_{12}, \mathrm{D}: \mathrm{NiP}_{4} \mathrm{O}_{11}, \mathrm{E}: \mathrm{P}_{4} \mathrm{O}_{10}$, references for the various phases are given in [1]). 
Quantitative expression for the redox behaviour of transition metal phosphates is there oxygen co-existence pressure. For decomposition of some phosphates of cobalt(II), nickel(II), and vanadium(III) these pressures have been measured as a function of temperature (700 $\left.1000^{\circ} \mathrm{C}\right)[6,7]$. Coulometric and potentiometric techniques $[8,9]$ were applied for these measurements of $\mathrm{P}\left(\mathrm{O}_{2}\right)$. The results obtained for some decomposition reactions are summarized in TABLE 1 .

TABLE 1 Oxygen decomposition pressures for selected phosphates of cobalt(II), nickel(II), and vanadium(III) at $900^{\circ} \mathrm{C}[6,7]$. Additionally, heats of formation $\Delta_{f} H^{\circ}{ }_{298}$ (phosphate) derived from the oxygen pressures are provided.

\begin{tabular}{|c|c|c|}
\hline decomposition reaction $^{\text {a) }}$ & $\begin{array}{l}\mathbf{P}\left(\mathbf{O}_{2}\right), 900^{\circ} \mathrm{C} \\
{[\mathrm{atm}]}\end{array}$ & $\begin{array}{l}\Delta_{f} H^{\circ}{ }_{298}(\text { phosphate }) \\
\text { [kcal/mol] }\end{array}$ \\
\hline $4 / 9 \mathrm{Co}_{3}\left(\mathrm{PO}_{4}\right)_{2, \mathrm{~s}}=2 / 9 \mathrm{Co}_{2} \mathrm{P}_{2} \mathrm{O}_{7, \mathrm{~s}}+4 / 9 \mathrm{Co}_{2} \mathrm{P}_{\mathrm{s}}+\mathrm{O}_{2,8}$ & $5.6 \cdot 10^{-17}$ & -613 \\
\hline $2 / 7 \mathrm{Co}_{2} \mathbf{P}_{2} \mathbf{O}_{7, \mathbf{s}}=4 / 7 \mathrm{CoP}_{\mathrm{s}}+\mathrm{O}_{2, \mathrm{~g}}$ & $5.6 \cdot 10^{-18}$ & -544 \\
\hline $8 / 11 \mathrm{Ni}_{3}\left(\mathrm{PO}_{4}\right)_{2, \mathrm{~s}}=6 / 11 \alpha-\mathrm{Ni}_{2} \mathrm{P}_{2} \mathrm{O}_{7, \mathrm{~s}}+4 / 11 \mathrm{Ni}_{3} \mathrm{P}_{\mathrm{s}}+\mathrm{O}_{2, \mathrm{~g}}$ & $1.8 \cdot 10^{-15}$ & -605 \\
\hline $38 / 49 \alpha-\mathrm{Ni}_{2} \mathbf{P}_{2} \mathbf{O}_{7, \mathrm{~s}}=14 / 49 \mathrm{Ni}_{2} \mathrm{P}_{4} \mathrm{O}_{12, \mathrm{~s}}+4 / 49 \mathrm{Ni}_{12} \mathrm{P}_{5, \mathrm{~s}}+\mathrm{O}_{2, \mathrm{~g}}$ & $1.3 \cdot 10^{-16}$ & -533 \\
\hline $1 / 2 \mathrm{VPO}_{4, \mathrm{~s}}=1 / 2 \mathrm{VP}_{\mathrm{s}}+\mathrm{O}_{2, \mathrm{~g}}$ & $1.3 \cdot 10^{-20}$ & -366 \\
\hline $\left.2(\mathrm{VO})_{2} \mathbf{P}_{2} \mathbf{O}_{7, \mathrm{~s}}=4 \mathrm{VPO}_{4, \mathrm{~s}}+\mathrm{O}_{2, \mathrm{~g}}{ }^{\mathrm{b}}\right)$ & $1.4 \cdot 10^{-12}$ & -798 \\
\hline $2(\mathrm{VO})_{2} \mathbf{P}_{2} \mathrm{O}_{7, \mathrm{~s}}=4 \mathrm{VPO}_{4, \mathrm{~s}}+\mathrm{O}_{2, \mathrm{~g}}{ }^{\mathrm{c})}$ & $1.4 \cdot 10^{-10}$ & -792 \\
\hline
\end{tabular}

Clearly, the measurements (TABLE 1) show for nickel and cobalt phosphates a decrease of $\mathrm{P}\left(\mathrm{O}_{2}\right)$ with increasing content of $\mathrm{P}_{4} \mathrm{O}_{10}$. This observation can be related to improved stabilisation of the metal oxide component in higher phosphates. Nickel(II) phosphates exhibit slightly higher oxygen pressures than the corresponding cobalt(II) phosphates. As expected, the decomposition of $\mathrm{VPO}_{4}$ to $\mathrm{VP}$ leads to even lower pressures, while at $900^{\circ} \mathrm{C}$ the oxygen co-existence pressure above vanadyl pyrophosphate is significantly higher. The different oxygen co-existence pressures for the decomposition of $(\mathrm{VO})_{2} \mathrm{P}_{2} \mathrm{O}_{7, \mathrm{~s}}$ to $\mathrm{VPO}_{4, \mathrm{~s}}$ (either in the presence of $\square_{2} \mathrm{~V}_{4} \mathrm{O}_{3}\left(\mathrm{PO}_{4}\right)_{3}$ or $\left.\mathrm{V}_{2}(\mathrm{VO})\left(\mathrm{P}_{2} \mathrm{O}_{7}\right)_{2}\right)$ indicate a homogeneity range for the diphosphate. In this sense, the two heats of formation derived for (VO) ${ }_{2} \mathrm{P}_{2} \mathrm{O}_{7, \mathrm{~s}}$ should be related to the $\mathrm{P}_{4} \mathrm{O}_{10^{-}}$and $\mathrm{VO}_{2}$-rich phase boundaries of $(\mathrm{VO})_{2} \mathrm{P}_{2} \mathrm{O}_{7, \text { s }}$, respectively [7].

\section{STABILISATION OF CATIONS WITH LOW OXIDATION STATES IN PHOSPHATES}

From our work we find that phosphates are particular suited to stabilize metals in rather low oxidation states. The series of chromium(II) phosphates $\left(\mathrm{Cr}_{2} \mathrm{P}_{2} \mathrm{O}_{7}\right.$ [10], $\mathrm{Cr}_{3}\left(\mathrm{PO}_{4}\right)_{2}$ [11], $\mathrm{Cr}_{3}^{2+} \mathrm{Cr}_{4}^{3+}\left(\mathrm{PO}_{4}\right)_{6}$ [3], $\mathrm{Cr}^{2+} \mathrm{Cr}_{2}^{3+}\left(\mathrm{P}_{2} \mathrm{O}_{7}\right)_{2}$ [12], known already for some time, and the rather new indium phosphates $\operatorname{In}^{1+} \operatorname{In}^{3+} \mathrm{P}_{2} \mathrm{O}_{7}$ [13] and $\left(\operatorname{In}_{2}^{4+}\right)\left(\operatorname{In}^{3+}\right)_{2} \mathrm{O}_{2}\left(\mathrm{PO}_{4}\right)_{2}$ [14]. Obviously, there is a particular tendency for the acidic oxide $\mathrm{P}_{4} \mathrm{O}_{10}$ to form stable compounds with rather basic oxides. This has the consequence that oxides of cations in low oxidation states are generally better stabilized by an solid state acid/base reaction with $\mathrm{P}_{4} \mathrm{O}_{10}$ than higher metal oxides. This general statement is supported by various experimental observations. Anhydrous chromium(II) phosphates are stable towards a disproportionation into chromium phosphides and chromium(III) phosphates despite the instability of "CrO" due to diproportionation into 
elemental chromium and $\mathrm{Cr}_{2} \mathrm{O}_{3}$. On the other hand, manganese(III) phosphates $\mathrm{MnPO}_{4}$ [15] and $\mathrm{Mn}\left(\mathrm{PO}_{3}\right)_{3}$ [16] exhibit rather low thermal stability and readily decompose to manganese(II) phosphates and oxygen, despite a much higher thermal stability of $\mathrm{Mn}_{2} \mathrm{O}_{3}$ itself [17]. The limits for acid/base stabilisation of low metal oxides are reached, when the metal oxide becomes strongly enough reducing that $\mathrm{P}_{4} \mathrm{O}_{10}$ itself is reduced to phosphorus or even phosphide. The missing of anhydrous titanium(II) and vanadium(II) phosphates and of $\mathrm{P}_{4} \mathrm{O}_{10}$-rich phosphates of chromium(II), too, can be rationalized along these lines. Especially the thermodynamic stability of a phosphate containing the transition metal in a medium oxidation state is a delicate balance between optimisation of the heat of neutralisation for the reaction of $\mathrm{MO}_{\mathrm{x}}$ with $\mathrm{P}_{4} \mathrm{O}_{10}$ and the gain in stability by further oxidation of the metal oxide.

\section{ELECTRONIC SPECTRA AND REDOX BEHAVIOUR}

In general anhydrous phosphates are well suited for the study of electronic spectra of transition metal ions [1]. Single crystals from chemical vapour transport experiments $[1,18]$, containing chromium(II), titanium(III), vanadium(III) or even molybdenum(III) are perfectly stable under ambient conditions. Phosphate anions with rather high chemical hardness normally allow observation of $d-d$ electronic transitions over a wide range of energy. Phosphates $\mathrm{MCr}_{2}\left(\mathrm{P}_{2} \mathrm{O}_{7}\right)_{2}(\mathrm{M}=\mathrm{Mg}, \mathrm{Co}, \mathrm{Zn})$ (FIGURE 3) visualize this fact. Electrons can only be excited from the oxygen p-states (LUMO) to the low lying metal d-states (HOMO) using UV light with $10 \geq 30000 \mathrm{~cm}^{-1}$. Only in the case of significantly oxidising cations (e.g. $\mathrm{Cu}^{2+}$ in FIGURE 3) the d-states are low enough in energy to allow easier excitation of ligand-metal charge transfer (LMCT) transitions. Strong inter valence charge transfer (IVCT) transitions leading to blue or even black colour are found for many mixed valence phosphates (e. g. with

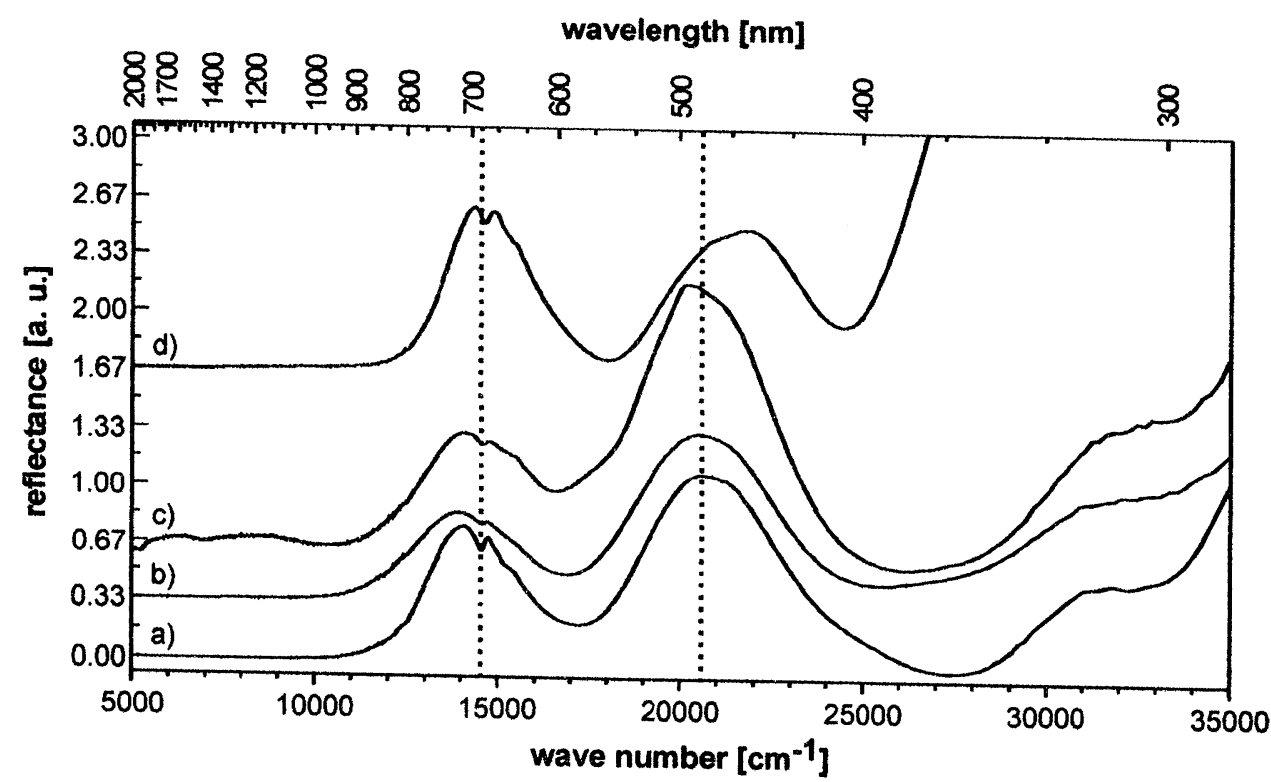

FIGURE 3 Electronic spectra of diphosphates $\mathrm{MCr}_{2}{ }_{2}\left(\mathrm{P}_{2} \mathrm{O}_{7}\right)_{2}$ [ 19]. The spectra of $\mathrm{ZnCr}_{2}\left(\mathrm{P}_{2} \mathrm{O}_{7}\right)_{2}(\mathrm{a}), \mathrm{MgCr}_{2}\left(\mathrm{P}_{2} \mathrm{O}_{7}\right)_{2}(\mathrm{~b})$, and $\mathrm{CoCr}_{2}\left(\mathrm{P}_{2} \mathrm{O}_{7}\right)_{2}$ (c) are almost identical showing the three spin-allowed transitions for an octahedral chromophor $\left[\mathrm{Cr}^{\mathrm{III}} \mathrm{O}_{6}\right]:{ }^{4} \mathrm{~A}_{2 \mathrm{~g}} \rightarrow{ }^{4} \mathrm{~T}_{2 \mathrm{~g}},{ }^{4} \mathrm{~A}_{2 \mathrm{~g}} \rightarrow$ ${ }^{4} \mathrm{~T}_{1 \mathrm{~g}}(\mathrm{~F}),{ }^{4} \mathrm{~A}_{2 \mathrm{~g}} \rightarrow{ }^{4} \mathrm{~T}_{1 \mathrm{~g}}(\mathrm{P})$. The latter, high-energy transition, is obscured in $\mathrm{CuCr}_{2}\left(\mathrm{P}_{2} \mathrm{O}_{7}\right)_{2}(\mathrm{~d})$. Hatched lines as guide for the eye. 
the redox pairs $\mathrm{Ti}^{3+/ 4+}$ in $\square_{2} \mathrm{Ti}_{4} \mathrm{O}_{3}\left(\mathrm{PO}_{4}\right)_{3}[2], \mathrm{V}^{2+/ 3+}$ in $\mathrm{V}_{2} \mathrm{O}\left(\mathrm{PO}_{4}\right)[20], \mathrm{Nb}^{4+/ 5+}$ in $\mathrm{NbO}_{1-\delta} \mathrm{PO}_{4}$ (blue to black depending on $\delta$ ) and $\mathrm{Nb}_{2}\left(\mathrm{PO}_{4}\right)_{3}[21,22], \mathrm{Mo}^{5+/ 6+}$ (blue in slightly oxygen deficient $\left.\left(\mathrm{MoO}_{2-\delta}\right)_{2} \mathrm{P}_{2} \mathrm{O}_{7}[23,24]\right), \mathrm{W}^{5+/ 6+}$ in monophosphate tungsten bronzes $\left(\mathrm{PO}_{2}\right)_{4}\left(\mathrm{WO}_{3}\right)_{2 \mathrm{~m}}$ $[25], \mathrm{Fe}^{2+/ 3+}$ in numerous iron phosphates $\left.[26,27]\right)$. In these cases, the colour indicates always a particular redox behaviour of the given element, followed by some sort of nonstoichiometry. Cases are rare in phosphate chemistry, where mixed-valency occurs with localized charges. As examples for this electronic situation the transparent chromium(II, III) phosphates $\left(\mathrm{Cr}_{7}\left(\mathrm{PO}_{4}\right)_{6}\right.$, brown [3]; $\mathrm{Cr}_{3}\left(\mathrm{P}_{2} \mathrm{O}_{7}\right)_{2}$, yellowish-green [28]) might serve.

\section{REFERENCES}

[1] R. Glaum, Neue Untersuchungen an wasserfreien Phosphaten der Übergangsmetalle (in german), Thesis of Habilitation, Univ. of Gießen, 1999. http://www.uni-giessen.de/ub/geb/geb info.htm.

[2] F. Reinauer, R. Glaum, R. Gruehn, Eur. J. Solid State Inorg. Chem. 1994, 31, 779.

[3] R. Glaum, Z. Kristallogr. 1992, $205,69$.

[4] R. Glaum, M. Weil, D. Özalp, Z. Anorg. Allg. Chem. 1996, 622, 1839.

[5] A. Schmidt, Ph. D. Thesis, Univ. of Gießen, 2002. http://bibd.uni-giessen.de/ghtm/2002/uni/d020105.htm

[6] M. Blum, K. Teske, R. Glaum, Z. Anorg. Allg. Chem. 2003, 629, 1709.

[7] T. Droß, Ph. D. Thesis, Univ. of Bonn, 2004. http://hss.ulb.uni-bonn.de/diss_online/math_nat_fak/ 2004/dross_thomas/index.htm

[8] K. Teske, $\bar{M}$. Al Daroukh, H. Langbein, H. Ullmann, Solid State Ionics 2000, 133, 121.

[9] K. Teske, H. Ullmann, N. Trofimenko, J. Therm. Anal. 1997, 49, 1211.

[10] R. Glaum, M. Walter-Peter, D. Özalp, R. Gruehn, Z. Anorg. Allg. Chem. 1991, 601, 145.

[11] A. Schmidt, R. Glaum, Z. Anorg. Allg. Chem. 1997, 623, 1672.

[12] R. Glaum, Z. Anorg. Allg. Chem. 1992, 616, 46.

[13] H. Thauern, R. Glaum, Z. Anorg. Allg. Chem. 2003, 629, 479.

[14] H. Thauern, R. Glaum, Z. Anorg. Allg. Chem. 2004, 630, 2463.

[15] C. Delacourt, P. Poizot, M. Morcrette, J.-M. Tarascon, C. Masquelier, Chem. Mater. 2004, 16, 93.

[16] M. Bagieu-Beucher, Acta Crystallogr. 1978, B34, 1443.

[17] A. Rossberg, H. Oppermann, R. Starke, Z. Anorg. Allg. Chem. 1987, 554, 151.

[18] R. Gruehn, R. Glaum, Angew. Chem. Intl. Ed. 2000, 39, 692.

[19] C. Litterscheid, part of planned Ph.D. thesis, Univ. of Bonn.

[20] R. Glaum, R. Gruehn, Z. Kristallogr. 1989, 186, 91.

[21] U. Kaiser, G. Schmidt, R. Glaum, R. Gruehn, Z. Anorg. Allg. Chem. 1992, 607, 113.

[22] A. Leclaire, M. M. Borel, A. Grandin, B. Raveau, Acta Crystallogr. 1989, C45, 699.

[23] P. Kierkegaard, Arkiv Kemi 1962, 19, 1.

[24] E. Benser, R. Glaum, unpublished results, Univ. of Bonn, 2003.

[25] P. Roussel, O. Pérez, Ph. Labbé, Acta Crystallogr. 2000, B57, 603.

[26] C. Gleitzer, Eur. J. Inorg. Solid State Chem. 1991, 28, 77.

[27] P. Schmid-Beurmann, J. Solid State Chem. 2000, 153, 237.

[28] R. Glaum, Z. Anorg. Allg. Chem. 1992, 616, 46. 